\title{
IAMJ
}

INTERNATIONAL

AYURVEDIC

MEDICAL JOURNAL

\section{A COMPARATIVE STUDY ON GHREYA VAMAKA YOGA}

\author{
Padmini $^{1}$ Ananta S Desai ${ }^{2}$, Rashmi ${ }^{3}$, Shridhara B S \\ ${ }^{1}$ PG Scholar, ${ }^{2}$ Professor\& HOD, ${ }^{3}$ Researcher, ${ }^{4}$ Joint Director \\ Department of PG Studies in Panchakarma SJIIM, Bengaluru, Karnataka, India
}

Corresponding Author: Paddu26jidagekar@gmail.com

\section{https://doi.org/10.46607/iamj1208112020}

(Published online: November 2020)

Open Access

(C) International Ayurvedic Medical Journal, India 2020

Article Received: 31/10/2020 - Peer Reviewed: 08/11/2020 - Accepted for Publication: 16/11/2020

\section{Check for updates}

\section{ABSTRACT}

The most important and widely used emetic is 'Madanaphala yoga' administered orally. While further elaborating the Vamana Karma classics also mentions that the persons who are reluctant to take medicine orally can be made to emit by giving the medicine as an errhine. With this classical background, the present study made an attempt to understand the olfactory route of medicine administration to induce Vamana against the oral route. Madanaphala (Randia Dumatorum) seed powder sprinkled over lotus and rose flower were used as Ghreya Vamaka Yoga in comparison with Madanaphala Yoga administered orally. Objectives: To evaluate the efficacy of Ghreya Yoga in inducing Vamana through Nasal Route. To evaluate the Olfaction effect through Rose medium, in comparison with Lotus medium. To evaluate the efficacy of Nasal route as against the Oral route. Methods: A Comparative clinical study done on 45 subjects of both sexes, between the age group of 21-50years who were randomly assigned into 3 groups namely- Group-A, Group-B and Group-C. Vamana karma with Ghreya Madanaphala Pippali Churna sprinkled on lotus flower, rose flower and Madanaphala pippali yoga administered orally. The Vamana karma was done in the following order: Purva karma, Pradhana karma \& Paschat karma. After the completion of the therapy, the results were assessed by comparing the data collected during the therapy. Result: Nasal route of administration of Vamaka yoga also works efficiently, Ghreya yoga worked in par with oral yoga \& Madanaphala Pippali Churna sprinkled over lotus and rose produced same effect in inducing Vamana. 
Keywords: Vamana, Madanaphala Pippali Churna, Ghreya Vamaka Yoga.

\section{INTRODUCTION}

Panchakarma, one of the major treatment procedures of Ayurveda operates to fulfil these objectives. Vama$n a$ (Therapeutic emesis) is the first and foremost Shodhana vidhi among the pentad of Panchakarma, which eliminates the increased Kapha and Pitta dosha through the mouth. ${ }^{1}$ The most important and widely used emetic is "Madanaphala yoga" administered orally. While further elaborating the Vamana Karma classics also mentions that the persons who are reluctant to take medicine orally can be made to emit by giving the medicine as an errhine. ${ }^{2}$ Several works have been carried out about conducting the Vamana by giving Madanaphala Yoga orally in treatment of many disorders, but no work has been taken up on "Ghreya Vamaka Yoga" up till today. So, there is uncertainty about the conduction, efficacy, and acceptance of procedure by the patient with respect to Ghreya Vamaka Yoga.

\section{Aim and Objectives:}

1. To evaluate the efficacy of Ghreya Yoga in inducing Vamana through Nasal Route.

2. To evaluate the Olfaction effect through Rose medium in comparison with Lotus medium.

3. To evaluate the efficacy of Nasal route as against the Oral route.

4. To understand the role of concept of Shiro Hridaya in the mode of action of Vamaka Dravya.

\section{Materials and Methods:}

The Research was initiated with the formation of thee groups namely Group-A, Group-B and Group-C. $V a$ mana karma was the common Panchakarma Therapy carried out in all the three groups with different $\mathrm{Va}$ mana Yogas. The Vamana karma was done in the following order: Nirameekarana \& Agni-Deepana with Chitakadi Vati, Snehapana with Murchita Ghrita, Sarvanga abhyanga with Tila Taila, Bashpa Sweda, Vamana, Dhumapana with Haridra dhuma Varti, Kavala with Ushna Jala and Samsarjana krama. After the completion of the therapy, the results were assessed by comparing the data collected during the therapy.
Research Design: A Comparative clinical trial was conducted by assigning the subjects into 3 groups. Group-A - 15 subjects received Vamana karma with Ghreya Madanaphala yoga sprinkled over lotus flower. Group-B - 15 subjects received Vamana karma with Ghreya Madanaphala yoga sprinkled over rose flower. Group-C - 15 subjects received Vamana karma with Oral Madanaphala yoga.

Source of Data: Individuals indicated for Vamana karma were selected from outpatient and in-patient Department of Shri Jayachamarajendra Institute of Indian Medicine, Dhanvantari Road. Bangalore- 9.

Sample size \& Grouping: The subjects were selected from the population of either sex, irrespective of religion, race, socio-economic status and education, satisfying the inclusion criteria. 46 subjects were selected out of which one subject dropped out. The remaining 45 subjects were allocated into 3 groups namely Group-A, Group-B and Group-C each group containing 15 subjects each. Grouping was done by Random sampling.

Data Collection: Subjects were thoroughly examined both subjectively and objectively. Detailed history pertaining previous ailment, previous treatment history, family history, habits, Ashtavidha Pareeksha and Dashavidha Pareeksha and physical examination findings were noted. Routine investigations were done to exclude any pathology. Subjects were registered for the present study with the help of proforma prepared for the study.

Duration of the study: For all three groups: Duration of the treatment -1 course

Fallow up period - 3-7 days

Inclusion Criteria:

$>$ Subjects indicated for Vamana.

$>$ Subjects between the age group of 20 to 50 years.

Exclusion Criteria:

$>$ Subjects contra-indicated for Vamana.

$>$ Patients suffering with other systemic chronic disorders like Diabetes mellitus, Tuberculosis, Hypertension, and Malignancy. 
$>$ Subjects of age group below 20 years and above 50years.

$>$ Subjects suffering from anosmia.

Intervention: Study was divided into Purvakarma, Pradhanakarma and Paschatkarma.

Purvakarm: 1. Preparation of the subject - Common for all the three groups

Agni deepana \& Nirameekarana: Citrakadi Vati was administered for 3 to 7 days in the dose of 2 tables 3 times a day $1 / 2 \mathrm{hr}$ before food, with warm water, till Nirama Laskhanas appeared. Snehapana: After achievement of Niramavastha, Murchita Ghrta was administered for the purpose of Snehapana. It was administered around 7.00 am when previous night's food had digested but hunger not yet appeared with Ushna Jala as Anupana. The dose of Ghee varied according to the subject, the initial dose of Ghee being $30-40 \mathrm{ml}$. It was generally elevated by $15 \mathrm{ml}$ to $50 \mathrm{ml}$. Thus, Arohana karma Snehapana was followed untill the appearance of Samyak Snigda Lakshnas. Svedana: Abhyanga with lukewarm Tila Taila was done for 30 mins. in 7 positions to the whole body followed by Bashpa Sveda till one felt profuse perspiration (usually 20-25 minutes), then advised to take rest for few minutes \& then hot water bath. Abhyanga and Svedana were administered on the gap day, and also on the day of Vamana just prior to the procedure. Diet before Vamana Karma: On the gap day, individual was instructed to have curd Vada, curd rice, milk \& rice, sweet preparation made out of milk. Manasopachara: On the previous day of Vamana, subjects were explained about the Vamana procedure in detail. The individual was then instructed to go to bed early \& to wake up around 5.00 a.m. in the morning.

2. Ghreya Yoga Avachurnana: Group A: Ghreya Madanaphala pippali churna was sprinkled over the lotus flower on the evening of Vishrama Dina. Group B: Ghreya Madanaphala Pippali Churna was sprinkled over the rose flower and the flower was covered with a plastic cover on the evening of Vishrama Dina.

3. Vamanagara: Vamanagara is made neat and tidy, equipped with all necessary medicines and materials, and the attendants were instructed about the procedure.
On the day of Vamana: Related to the materials Ghreya Yoga Avachurnana: Ghreya Madanaphala pippali Churna was once again sprinkled in the morning over the lotus flower and rose flower in group A and group B respectively. Preparation of Madanaphala Yoga: Madanaphala pippali churna, Vacha churna and Saindhava lavana in the specified quantity were mixed with sufficient quantity of Madhu to bring the yoga to Lehya consistency. Yashtimadhu Phanta was prepared. Ksheera was made lukewarm. Related to the subject - On the day of Vamana, subject was made to get up early in the morning around 5am, advised to pass natural urges. Sarvanga Abyanga and Bashpa Sweda followed by hot water bath was performed. Subject was made to sit in a comfortable position in the Vamana Peeta and covered with a white cloth.

Pradhanakarm: For Group A - Dhanvantari Prartana was done. Pulse, Blood Pressure, Heart rate and Respiratory rate were recorded. Subject was made to take Akanta Pana of Ksheera (upto 1.8 ltrs.) mixed with Saindhava Lavana (5g.) and jaggery (50g.). Vitals were recorded. Ghreya Madanaphala Yoga sprinkled on lotus flower was made to inhale by the subject. Signs of Sweda Pradurbava, Romaharsha, Kukshi admana, Hrillasa, Praseka if appeared were noted. If Vega started immediately, the time of Vega and nature of vomitus were recorded and waited for next Vega. Yashti Madu Phanta was administered to continue the procedure. Every time, number of Vega, nature of vomitus, pulse, B.P were noted. During each $V e g a$, subject was educated to bow properly to open the mouth widely for expelling the vomitus without any discomfort. Massage over the back $\&$ sides of the vertebral column was made in upward direction, forehead was held firmly, gentle pressure was given over the abdomen. Warm water was used for washing hands. Finger tickling of Talu Pradesha was advised if initiation of Vega was less. Procedure was continued till the appearance of Pittanta Lakshanas like appearance of Pitta, Katu- Tikta Asyata, Kanta Daha. Lukewarm Saindhava Jala was administered at the end. Time was noted at each step of the procedure. Once again BP, Pulse were recorded. 
For Group B -The procedure is same as of group A except that the medicine used here is Ghreya Madanaphala Yoga sprinkled on rose flower. For Group CAkanta Pana is done with milk and Madanaphala Yo$g a$ is administered orally. Otherwise the procedure is same as of group A.

Paschat Karma: After completion of Vamana procedure, again vital data were recorded. Subject is made to wash face, hands and legs, and to sit down comfortably. After 45 minutes of rest, Dhumapana was done. Gargling with hot water was advised, was instructed not to sleep in the afternoon, not to sit under fan or near the window, not to rove outside in the flowing winds \& sunlight and was advised to have a rest on the bed. The individual was instructed not to have any food article till the appearance of hunger $\&$ till that time, if needed one may use lukewarm water to drink.

Samsarjana Krama: Depending upon type of Shuddi, Samsarjana Krama was planned for 7, 5, 3 days respectively. In case of Hina, Madhyama or Uttama Shuddhi Peya-Vilepi-Mudga Yusa and Rice with Mudga Yusa were served for one mealtime, two meals time and three meals time respectively starting from the evening of the Vamana day.

Follow up - Follow up done for three, five or seven days based up on the type of Shuddhi until the completion of Samsarjana Karma.

Assessment criteria: Assessment was done based on the following parameters:

1. Time taken for the initiation of bout (in minutes): Calculated by subtracting the time of administration of Madanaphala yoga from the time of appearance of first Vega.

2. Total time duration of the therapy (in minutes).

3. Vegiki Shuddhi (Number of bouts).

4. Maniki Shuddhi (Total volume of morbid factors expelled in $\mathrm{ml}$.): Calculated by subtracting the input volume from output volume.

5. Antiki Shuddhi (End product of Emesis- grading is done) - Grade 0 - No antiki shuddhi appeared, Grade 1 - Oushadhanta, Grade 2 - Kaphanta, Grade 3 - Pittanta

6. Laingiki Shuddhi (Signs \& Symptoms of purification produced by the therapy): Total score is 13 .
7. Weight reduction (in kgs.).

8. Shuddhi (Overall assessment of therapy as per classics): Grading done. Grade 0 - No Shuddhi appeared, Grade 1 - Avara Shuddh, Grade 2 Madhyama Shuddhi, Grade 3 - Pravara Shuddhi

\section{OBSERVATION}

A total number of 46 subjects fulfilling the inclusion criteria were studied.

- Number of subjects registered for the study -46 , Number of subjects completed the study -45 , Number of dropout - 01

- Observations were made under the following headings:

A. Demographic data B. Therapeutic data

A. DEMOGRAPHIC DATA: AGE: Out of 46 subjects, $67.27 \%$ (maximum) were in the age group of 21-30 years, and $11 \%$ (minimum) were in the age group of 41-50 years. SEX: Among the 46 subjects registered, majority of the subjects were females $(82.46 \%)$ and the rest of the subjects $(17.54 \%)$ were males. RELIGION: In this study most of the individuals were Hindus (86.8\%), Christians were $11.03 \%$ and the remaining $2.17 \%$ individuals were Muslims. HABITAT: Maximum i.e. $88.97 \%$ subjects were from urban population while $11.03 \%$ were from rural population EDUCATIONAL STATUS: 71.61\% subjects were graduates, $13.11 \%$ each were having education up to $10^{\text {th }}$ std. and $12^{\text {th }}$ std., and $2.17 \%$ individuals were educated up to post graduation. SOCIOECONOMIC STATUS: Majority of the subject belonged to upper middle class $(71.61 \%), 21.73 \%$ were in lower middle class and $6.66 \%$ were poor OCCUPATION: Maximum number of subjects were students $(41.38 \%), 28.21 \%$ were doing office work, $21.73 \%$ were house wives and remaining $8.68 \%$ were doing other job. MARITAL STATUS: Among the 46 subjects, a maximum of $65.28 \%$ subjects were unmarried, while $30.38 \%$ were married and $4.34 \%$ were widows. DIET: In this study, $60.76 \%$ subjects were of mixed diet and remaining $39.24 \%$ were of vegetarian diet. AGNI: In the present study, maximum number of subjects (39.21\%) were having Mandagni, 21.73\% subjects were of Samagni and $19.53 \%$ each were of 
Vishamagni and Teekshnagni. KOSHTA: Among 46 subjects, $69.35 \%$ subjects were having Madhyama koshta followed by Mrudu koshta in 17.54\%subjects and Krura koshta in $13.11 \%$ subjects. PRAKRITI: Maximum number of subjects (39.24\%) belonged to Pitta Kapha prakriti, followed by Vata Kapha prakriti (23.87\%), Kapha Pitta prakriti (15.1\%), Kapha Vata prakriti (13.11\%) and Vata pitta prakriti (8.68\%). SATVA: $56.6 \%$ (maximum) subjects belonged to Madhyama Satva, while $23.87 \%$ subjects had Pravara Satva and 19.53\% subjects had Avara Satva. VYAYAMA SHAKTI: Vyayama Shakti was Madhyama in $78.27 \%$ subjects and $21.73 \%$ subjects had Pravara Vyayama Shakti. SARA: Table No. 73 and Graph No.15 shows that maximum number of subjects $88.97 \%$ were of Madhyama Sara and the remaining $11.03 \%$ subjects were of Pravara Sara. HEALTH STATUS: In the present study, maximum number of subject $(23.87 \%)$ were healthy volunteers, $19.53 \%$ subjects each were having Kitibha and Sthoulya, $11.03 \%$ subjects were having Kaphaja Galaganda, $8.68 \%$ subjects each were having much Dushika and Tamaka Shvasa, and 4.34\% subjects each were suffering from Pratishyaya and Sheeta Pitta. BODY WEIGHT: Among 46 subjects, maximum number of subjects $(41.38 \%)$ had weight in between $51-60 \mathrm{kgs}$. Followed by $21.73 \%$ subjects in the weight group of $61-70 \mathrm{kgs} ., 15.1 \%$ subjects in the weight group of $71-$ $80 \mathrm{kgs} ., 13.11 \%$ subjects in the weight group of $41-$ $50 \mathrm{kgs}$., and $4.34 \%$ subjects each in the weight group of $81-90 \mathrm{kgs} \& 91-100 \mathrm{kgs}$.

\section{B.1) THERAPEUTIC DATA OF PURVA KARMA} NIRAMEEKARANA \& AGNI DEEPANA: Among 45 subjects, who completed the study, maximum number of subjects (44.4\%) achieved Agni Deepana and Niramavastha in 3 days, followed by $24.42 \%$ subjects each in 4 days \& 5 days and one subject in 7 days. SNEHAPANA PRAKARSHA KALA: 79.88\% subjects (maximum) achieved Samyak Snigdh Lakshanas in 3 days, while $17.76 \%$ took 4 days and one subject took 5 days. SAMYAK SNIGDHA LAKSHANA: Among 45 subjects, 100\% individuals achieved Deeptagni, Vatanulomana. Snigdha Varcha and Anga Laghava Lakshanas. Mrudu Gatra was achieved by $97.62 \%$ subjects, Asamhata Varcha by $95.4 \%$ subjects, Snehodvega by $88.76 \%$ subjects, Snigdha Gatra by $86.54 \%$ subjects and Glani by 79.88\% subjects. Samyak Svinna Lakshana: All the Samyak Svinna Lakshanas appeared in 100\% subjects. B.2) THERAPEUTIC DATA OF PRADHANA KARMA

SYMPTOMS AFTER ADMINISTRATION OF VAMAKA YOGA: The symptom Hrllasa appeared in maximum no. of subjects $(88.76 \%)$, followed by Sveda Pradurbhava in $84.32 \%$ subjects, Kukshi Adhmana in $73.22 \%$ subjects and Roma Harsha in $19.98 \%$ subjects. TIME TAKEN FOR VEGA PRAVRUTTI: The first Vega started with in $1-5 \mathrm{~min}$. in $68.78 \%$ (maximum) subjects followed by within 21-25 min. in $15.54 \%$, with in 6-10 min., 16-20 min., 26-30 min. in $4.44 \%$ subjects each and within $11-15$ min. in $2.22 \%$ subject. TOTAL DURATION TAKEN FOR THE PROCEDURE: $28.86 \%$ subjects each completed Pradhana Karma in 21-30 min. \& 31-40 min., where as $15.54 \%$ subjects completed within 11-20 min., $13.32 \%$ subjects completed in $51-60 \mathrm{~min}$. and $6.66 \%$ each finished within 41-50 min. \& 61-70 min. NUMBER OF VEGA: $33.3 \%$ subjects had 8 Vegas, while $24.42 \%$ had 6 Vegas, $22.2 \%$ had 7 Vegas and $19.98 \%$ subjects had 5 Vegas. MANIKI SHUDDHI: Among 45 subjects, 53.28\% had Maniki Shuddhi with in $100 \mathrm{ml}$. whereas $26.64 \%$ subjects had within 101-200 $\mathrm{ml}, 6.66 \%$ had within $401-500 \mathrm{ml} ., 4.44 \%$ each had within 201-300ml. \& 301-400ml. and one subject each had Maniki Shuddhi of $750 \mathrm{ml} \& 900 \mathrm{ml}$. Antiki Shuddhi: Maximum no. of subjects (95.4\%) had Pittanta Shuddhi while $4.44 \%$ subjects had Kaphanta Shuddhi. Laingiki Shuddhi: Maximum no. of Samyak Shuddhi Lakshanas (13) were found in $11.1 \%$ subjects followed by 12 symptoms in $17.76 \%, 11$ in $33.3 \%, 10$ in $15.54 \%, 9$ in $17.76 \%$ and 8 in $4.44 \%$ subjects. OVERALL SHUDDHI: $53.28 \%$ subjects achieved Madhyama Shuddhi while $46.62 \%$ subjects achieved Uttama Shuddhi. WEIGHT REDUCTION: Most of the subjects (51.06\%) achieved weight loss within 1-2 kgs. Remaining $31.08 \%$ subjects had weight loss between 2.1-3 kgs. Followed by weight reduction of 3.1$4 \mathrm{Kgs}$, in $13.32 \%$ and $4.1-5 \mathrm{kgs}$.in $4.44 \%$ subjects. 
Results: The Statistical Analyses is done by using completely Randomized Design, by assuming that, $\mathrm{H}_{\mathrm{O}}$ : The mean effect is same an all the parameter in three groups. $H_{1}$ The mean effect is not same an all the parameter in three groups.

Table 1: Showing Final Result

\begin{tabular}{|l|l|l|l|l|l|}
\hline Sl. No. & Parameter & & Group A & Group B & Group C \\
\hline 1 & Time taken for the initiation of Vega & Mean & 1.53 & 2.73 & 19.13 \\
\hline & & SD & 0.83 & 1.9 & 7.34 \\
\hline 2 & Total Duration taken for the process & Mean & 30.46 & 26.86 & 48.8 \\
\hline & & SD & 11.11 & 8.3 & 14.33 \\
\hline 3 & No. of Vega & Mean & 6.93 & 6.66 & 6.46 \\
\hline & & SD & 1.03 & 1.23 & 1.18 \\
\hline 4 & Maniki shuddhi & Mean & 160 & 256 & 153.33 \\
\hline & & SD & 160.57 & 269.8 & 93.47 \\
\hline 5 & Antiki shuddhi & Mean & 3 & 2.93 & 2.93 \\
\hline & & SD & 0 & 0.25 & 0.25 \\
\hline 6 & Laingiki shuddhi & Mean & 10.8 & 11.06 & 10.4 \\
\hline & & SD & 1.42 & 1.33 & 1.35 \\
\hline 7 & Weight Reduction & Mean & 2.23 & 2.6 & 2.46 \\
\hline 8 & & SD & 0.89 & 0.96 & 1.27 \\
\hline & Overall shuddhi & Mean & 2.53 & 2.46 & 2.4 \\
\hline
\end{tabular}

Table 2: For the Parameter time taken for the initiation of Vega (Bout) ANOVA

\begin{tabular}{|l|l|l|l|l|l|l|l|}
\hline $\begin{array}{l}\text { Source of Varia- } \\
\text { tion }\end{array}$ & $\begin{array}{l}\text { Degrees of } \\
\text { Freedom }\end{array}$ & $\begin{array}{l}\text { Sum of } \\
\text { Squares }\end{array}$ & $\begin{array}{l}\text { Mean Sum of } \\
\text { Squares }\end{array}$ & $\begin{array}{l}\text { F-Calculated } \\
\text { Value }\end{array}$ & $\begin{array}{l}\text { F-Table } \\
\text { Value @ 5\% }\end{array}$ & $\begin{array}{l}\text { P- } \\
\text { Value }\end{array}$ & Remarks \\
\hline $\begin{array}{l}\text { Between the } \\
\text { Groups }\end{array}$ & 2 & 2959.512 & 1479.756 & 85.55 & 3.23 & $<0.005$ & HS \\
\hline $\begin{array}{l}\text { Within in the } \\
\text { Groups }\end{array}$ & 42 & 726.4 & 17.295 & & & & \\
\hline Total & 44 & 3685.92 & & & & & \\
\hline
\end{tabular}

From the analysis the mean effect of the parameter time taken for the initiation of Vega (Bout) of the three groups shows Highly Significant Result, (as $\mathrm{P}<0.005)$. It implies that the mean effect of the parameter time taken for the initiation of Vega (Bout) of the three groups is not same. To know in which group the treatment means differ significantly, we use Critical difference $(C D)$ i.e. the least difference between any two means to be significant. The Least significance difference Value is 6.8624Table no.93 Shows which Groups is Significant for the Parameter time taken for the initiation of Vega (Bout)

Table 3:

\begin{tabular}{|l|l|l|l|}
\hline Group & Mean effect & Difference from C & Difference from B \\
\hline C & 19.133 & - & - \\
\hline B & 2.733 & 16.412 & - \\
\hline A & 1.533 & 17.6 & 1.2 \\
\hline
\end{tabular}

Comparing these differences with Critical difference we found that
1. Group A differs more significantly from B and C.

2. Group B differs significantly from $\mathrm{C}$. 
3. If choice is to be made among the three groups group $\mathrm{A}$ is the best and most effective.

4. If choice is to be made between B and C, Group B is to be preferred.

\section{DISCUSSION}

Purva Karma: Pachana denotes one of the modalities of treatment used to treat moderately vitiated Dosha. Hence, it will be appropriate to use the word Nirameekarana instead of Pachana. Role of Snehana and Swedana: Shodhana Chikitsa requires Dosha udeernavastha for Dosha nirharana as the principle goes 'Vrddhaha Nirhartavyaha'. Thus, to achieve this, Snehana and Swedana are the foot- steps. Application of Snehana and Swedana bring the vitiated dosha situated in the Shaka to the Koshta by the actions of Vrddhi, Vishyandhana, Paka, Sroto Mukha Vishodhana and Vatanulomana, which are later eliminated from the body through Vamana. Manasopachara: It plays a vital role in the smooth conduction of Vamana procedure and contributes a major part to get desired result. Pradhana karma: Performing Vamana karma during Pratah Kala is of importance to obtain fruitful effects from Vamana. Madhu and Saindhava Lavana which are generally used in all formulations are an exception for Ghreya Yoga. Paschat Karma: Procedures explained under this heading help the body to come back to normalcy. The Laingiki and Antiki Lakshanas are indicative of Samyak Yoga or Ayoga of Vamana, where as Manaki and Vaigiki Lakshanas help to assess Pravara, Madhyama or Avara Shuddhi. These Lakshanas also help in planning the Samsarjana Krama

Anatomical Review: Ghrana - As per Parishadya Shabdartha Shareera, Ghrana has been explained as that specific part of the Nasa which gives shelter for Ghranendriya. That which perceives smell is said as Ghrana. It is also the site of Phana Marma injury to which leads to Gandha Ajnana (anosmia). Thus, Ghrana can be taken as the olfactory portion of the nose. Gandhavaha Dhamani - They are enumerated as 2. They have been equated with olfactory nerves. Hrudaya - The term Hrudaya refers to not only uro Hrudaya but also Shiro Hrudaya. Some of the points which substantiate this statement are as follows: The Sthana and Karma of Prana Vata denotes both Shiro and Uro Hrudaya. Vyana Vata Karma implies involvement of both nervous system and circulatory system. Shiro Hrudaya is the seat of sthana and Karma of Sadhaka Pitta. The act of Nidra Invoving Hrudaya definitely points out Shiro Hrudaya.

Mode of Action of Vamaka Aushadhi: The Vamana Aushadhi possesses qualities like Ushna, Tikshna, Sukshma, Vyavayi and Vikasi with dominance of Agni and Vayu Mahabhutas with the major contribution of Urdhva Bhagahara Prabhava. The drugs due to their Virya will reach Hridaya and through Dhamani, thereby reaches Sthula and Anu Srotases of the body. The Vyavayi Guna of the drug will help in quick absorption and movement of the drug. Vikasi Guna will help in breaking the binding of the morbid DoshaDushya. Due to Ushna Guna drug will cause Vishyandana and due to Tikshna Guna causes Chedana of the Doshas. The Sukshma Guna helps to reach the minute Channels. The Agni and Vayu Mahabhutas because of their qualities and due to Urdhva Bhagahara Prabha$v a$ (tendency to move upwards) bring the act of Vamana.

Probable Mode of Action of Ghreya Vamaka Yoga: Ghreya Madanaphala Yoga was prepared by giving twenty-one times bhavana to Madana Pippali Churna with Madanaphala Kashaya leading to enhancement of its potency because of the bhavana samskara. Thus, the Ghreya yoga differs significantly from Madana Pippali Churna. Such a Ghreya Yoga when given for inhalation is perceived by the Ghranendriya located in the Nasa and carried by the Gandhavaha Dhamani the Shiro Hrudaya(higher centres in the brain).Initiates Vyana Vata to bring Dosha from Shaka to Koshta. Due to Urdhva Bhagahara Prabhava and stimulation of Udana Vata, Vamana Vega occurred.

Discussion on materials and methods: Materials: Collection \& Processing of Madanaphala - During samskara, impregnation of Madana Pippali in honey changed its consistency. Honey became thin after completion of Samskara. Ghreya Madanaphala Yoga - Madanaphala Churna after the bhavana process turned to dark in colour with increased offensive 
smell. Methodology: The study was oriented only towards the conduction of therapy. Hence, not much importance was given to diseased or healthy condition of the subject and as such both healthy and diseased subjects were taken for the study. 46 subjects were registered for the study out of which one subject opted out of the study in the middle due to ill health.

\section{Discussion on Result:}

Ghreya Yogas initiated Vamana Vega quickly than orally administered yoga. Lotus group was more efficient than rose group. Ghreya yoga reaches Hrudaya faster than the oral one. Duration was less in Ghreya group than oral group. In rose group, procedure completed earlier than lotus group. The mean effect is same in all the three groups that is Ghreya Yogas were able to produce Vegas like oral yoga. By comparing the mean values, it can be said that Vegas were more in lotus group than in rose group. The mean effect is same in all the three groups that is Ghreya Yogas were able to produce overall Shuddhi like oral yoga. By comparing the mean values, it can be said that overall Shuddhi was more in lotus group than in rose group. No significant differences were observed in the results of parameters Vegiki, Maniki, Antiki, Laingiki and Overall shuddhi and in weight reduction. Highly significant results were found in the parameters time taken for the initiation of Vega and total duration taken to complete the procedure in which the Ghreya Madanaphala Yoga performed better in comparison with Madana Pppali yoga administered orally. Early initiation of the Vega and reduction in the total time duration eased the Vamana procedure by minimizing the stress and strain for the subjects. Apart from the time factor, the Ghreya yoga was more easily accepted by the subjects without any hesitation and discomfort. This was probably because of the fact that it does not come in contact with the sense of taste which is the main hindrance for orally administered yoga. The Madanaphala yoga which was bitter in taste was swallowed with great difficulty by the subjects, many a times was thrown out before entering the body.

\section{CONCLUSION}

Vamana, a Shodhana Rupi Chikitsa has been dealt as an important Panchakarma therapy. Acharya Charaka alone has mentioned 355 formulations to perform Vamana among which only few Yogas are in practice. To revalidate the efficacy of all formulations is the need of the hour. Vamana karma plays a vital role in Svastya Rakshana and Vikara Prashamana. Nasal route of administration of Vamaka Yoga also works efficiently. Ghreya Yoga worked in par with oral yoga. Madanaphala Pippali Churna sprinkled over lotus and rose produced same effect in inducing Vamana. Time factor showed significant result in Vamana produced by Ghreya Yoga.

\section{REFERENCES}

1. A. C. Guyton and J.E. Hall. Textbook of Medical Physiology, $9^{\text {th }}$ ed. Bangalore: Prism books (Pvt) LTd.; 1996.

2. Agnivesha. Charaka Samhita, annotated by Charaka and redacted by Dridhabala with the Ayurveda Dipika commentary of Chakrapani Datta, edited by Yadavji Trikamji Acharya. $4^{\text {th }}$ ed. Varanasi: Choukambha Sanskrit Sansthan;1994.738pp.

3. Bhavamishra, Bhavaprakssha, Vidyotini Hindi Commentary, Pandit shri Bramhashakar Mishra, Varnasi: Chowkhamaba Sanskrit Samsthana; 2003.

4. Bhela, Bhela Samhita, Sutrasthana, with English Translation by Krishnamurthy K.H., Varanasi; Chaukhambha Vishwabharati. Reprint 2005

5. Chakrapanidatta, Chakradatta, A treatise on Principles and Practices of Ayurvedic Medicine, edited and translated by P.V. Sharma, 3rd ed. Varanasi: Choukhambha publishers; 2002.731pp.

6. Chatterjee C.C, Human Physiology, Vol-1, 9th chapter, Calcutta; Medical Allied Agency, Reprint-1998.

7. Davidson, Principles and Practice of Medicine, Christopher Haslett editor,

8. London; Churchill Livingstone, 18th edition, 1999.

9. Govinda Das Sen. Bhaishajya Ratnavali, with Chandra prabha vyakhya, $8^{\text {th }}$ ed. Delhi: Motilal Banarasidass; 1970.

10. Haragovind Shastri, Manusmriti, Gopal shastri nene, editor. Varanasi: Chaukhambha Sanskrit Sansthan, 7th edition.

11. J.L.N.Shastry. Dravyaguna Vijnana,Vol. II, Varanasi Chowkhamba Bharati academy, 7th edition, 1983. 
12. Parishadhyam Shabdartha Shareeram Anatomical Terminology of Ayurveda, edited by Pt.Damodarsharma Goud. $1^{\text {st }}$ ed.Calcutta:Baidyanath Ayurveda Bhavan Private Limited;1964,pp21

13. Raja Radha Kanta deva, Shabda Kalpadruma., Varanasi, chowkhamba Sanskrit series, III edition, 1967.

14. Sharangadhara, Sharngadhara Samhita,with the commentaries Adhamalla's Dipika and Kashirama's Gudhartha-Dipika,edited by Pt.Parashuram Shastri Vidyasagar, 3rd ed. Varanasi: Krishnadas Academy;2000, 398pp.;2

15. Sir. Monier Monier - Williams, A sanskrit - English dictionary, $1^{\text {st }}$ Indian ed. Delhi: Motilal Banarasidass; $1970,1333 \mathrm{pp}$.

16. Stedman, Medical dictionary, $22^{\text {nd }}$ ed. Baltimore: The Williams and Wilkins Company; 1975,1533 pp.

17. Sushruta, Sushruta Samhita, the Nibandha Sangraha commentary by Dalhanacharya and the Nyayachandrika Panjika of Sri. Gayadasacharya on Nidana Sthana, edited by Vaidya Jadavji Trikamji Acharya and Narayanarama Acharya, Kavyatirtha, $7^{\text {th }}$ ed. Varanasi:Chaukambha orientalia; 2002,824pp.

18. Vagbhata. Ashtanga Hridayam with Sarvanga Sundari Teeka of Arundatta and Ayurveda Rasayana teeka of Hemadri, Reprint Edition, Varanasi: Krishnadas Academy; 2000,956 pp

19. Vaidya Haridas Sridhara Kasture.Ayurvediya Panchakarma Vignana, $6^{\text {th }}$ ed. Calcutta: Sri Baidyanatha Ayurveda Bhavan Limited; 1999,712pp.

20. Vanga Sena, Chikitsa Sara Sangraha, Bhattacharya Jeevananda Vidya Sagar, Calcutta, 2nd edition, 1893, pp 907, 908, 916,917.

21. Vruddha Jeevaka. Kashyapa Samhita, translated to English by P.V. Tiwari, $2^{\text {nd }}$ ed. Varanasi: Choukambha Vishwabharathi Oriental Publishers \& Distributors; 1996.

22. wikipedia.org

\section{Source of Support: Nil \\ Conflict of Interest: None Declared}

How to cite this URL: Padmini: A Comparative Study On Ghreya Vamaka Yoga. International Ayurvedic Medical Journal \{online\} 2020 \{cited November, 2020\} Available from: http://www.iamj.in/posts/images/upload/5031 5039.pdf 